\title{
PENERAPAN MODEL PEMBELAJARAN PROBLEM-BASED LEARNING (PBL)TERHADAP HASIL BELAJAR SISWA SMAN 7 PALU KELAS XI PADA MATERI LARUTAN PENYANGGA
}

\author{
Application of the Problem Based Learning (PBL) Model to the Learning of Student SMAN 7 \\ Palu on Buffered Solution Subject
}

\author{
*Amsar T. Beddu, Sri Mulyani Sabang dan Purnama Ningsih \\ Pendidikan Kimia/FKIP - Universitas Tadulako, Palu - Indonesia 94118
}

Received 4 December 2017, Revised 2 January 2018, Accepted 1 February 2018

\begin{abstract}
This research aims to investigate the result of a study in applying the model of problem-based learning (PBL) the students of SMAN 7 Palu on the topic buffer. This method use quasy experiment with pretest-posttest control group design. The population is a class XI students of SMAN 7 Palu, where the sample is a 23 students in class XI IPA 3 as the experimental group and 23 students in class XI IPA 4 as the control group, which is determined by purposive sampling. The result of student learning to the average value of the experimental class is bigger than for class control experiment was 82.61 and for the control, class is 8.65. Test normality using the KolmogorovSmirnov test values obtained for the experimental class Sig $0.20>0.05$ and class control $0.20>0.05$, it means that both at data are normally distributed. Homogeneity test using the test statistics Lavene which gained value of $F_{\text {calc }} 0.37>0.54 F_{\text {table }}$ for experimental classes 0.20 Sig $>0.05$ and for grade control $0.20>0.05$, it means that both of normally distributed data, there is similarities variant between a group or the means homogeneous. Testing hypothesis use t-test two parties where the significance value of 0.06, it means at the value of Sig $>0.05$, that Ho rejected and Ha accepted. Based on the statistical test, PBL learning model on material buffer has a positive influence on results for students at SMAN 7 Palu.
\end{abstract}

Keywords: Learning model, PBL, buffer, learning outcome, high school.

\section{Pendahuluan}

Pendidikan di sekolah pada dasarnya merupakan kegiatan belajar-mengajar, yaitu adanya interaksi antara siswa dan guru. Proses belajarmengajar bertujuan untuk mengembangkan seluruh potensi yang ada pada diri siswa secara optimal. Prestasi siswa tersebut dapat semakin terlihat jika diimbangi dengan kualitas belajarmengajar yang lebih baik. Pembelajaran di kelas hendaknya disesuaikan dengan tujuan pembelajaran dan kondisi siswa di kelas, sehingga akan terjadi interaksi guru dan siswa yang lebih optimal. Model pembelajaran yang bervariasi dapat digunakan guru untuk mengoptimalkan potensi siswa, khususnya pada mata pelajaran yang dianggap sulit oleh beberapa siswa (Sholihah, 2010).

Penggunaan model pembelajaran adalah suatu usaha yang dilakukan oleh guru agar seorang siswa dapat maksimal dalam memahami materi pelajaran, sehingga setelah melakukan pembelajaran siswa akan meningkat kompetensinya sebagaimana tuntutan dari materi pelajaran yang dipelajari. Berbagai macam kegiatan pembelajaran yang diimplementasikan mempunyai

\footnotetext{
${ }^{*}$ Correspondence

Amsar T. Beddu

Program Studi Pendidikan Kimia, Fakultas Keguruan dan

Ilmu Pendidikan, Universitas Tadulako

e-mail: putra.batanggalang@gmail.com

Published by Universitas Tadulako 2018
}

karakteristik tertentu dengan segala kelebihan dan kelemahan masing-masing (Rubi, 2012).

Penggunaan model pembelajaran berpusat pada guru tentunya diharapkan untuk mewujudkan kondisi yang mendorong siswa sehingga termotivasi melakukan kegiatan belajar secara aktif. Kenyataan di lapangan menunjukkan bahwa tercapainya proses belajar mengajar yang efisien, bukan karena hanya dengan berpusat pada guruatau komunikasi satu arah, akan tetapi harus juga dengan metode pembelajaran yang berpusat pada siswa. Apabila hal ini tidak bersinergi, maka akan mempengaruhi kualitas pendidikan menjadi rendah (Rahayu, 2012).

Berdasarkan pengamatan yang dilakukan terhadap siswa di SMAN 7 Palu pada bulan Agustus 2014, rendahnya hasil belajar siswa ditunjukkan oleh banyaknya siswa yang nilainya belum mencapai kriteria kelulusan minimal (KKM) yaitu 70. Masalah lain yang dihadapi di SMA adalah siswa masih banyak yang enggan bertanya kepada guru tentang materi pembelajaran yang belum dimengerti, adanya anggapan bahwa pembelajaran kimia itu sulit tetapi menarik, masih kurangnya kerjasama antar teman dalam pembelajaran, siswa terkesan bahwa guru sebagai satu-satunya sumber belajar (konvensional), dan belum dilakukannya model pembelajaran yang dianggap dapat meningkatkan keaktifan dan hasil belajar siswa.

Pelaksanaan kegiatan proses belajar mengajar tidak terlepas dari berbagai masalah belajar. Salah satunya berkaitan dengan masalah keterampilan belajar. Belajar adalah suatu proses yang ditandai 
dengan adanya perubahan pada diri seseorang, perubahan sebagai hasil dari proses belajar dapat ditunjukkan dengan berbagai bentuk, seperti pengetahuan, pemahaman, sikap dan tingkah laku, kecakapan, kemampuan, daya kreasi, daya penerimaan dan lainnya yang ada atau terjadi pada individu tersebut (Sudjana, 2010).

Masalah belajar adalah suatu kondisi tertentu yang dialami oleh seorang individu yang menghambat kelancaran proses belajarnya. Masalah belajar yang dialami oleh siswa berkaitan erat dengan keterampilan belajar. Keterampilan belajar adalah suatu keterampilan yang harus dikuasai oleh seorang siswa untuk dapat sukses dalam menjalani pembelajaran di sekolah (sukses akademik) dengan menguasai materi yang dipelajarinya (Tosun, 2011).

Wahyudi (2014) mengungkapkan bahwa model pembelajaran PBL adalah model pembelajaran yang menuntut siswa mengembangkan keterampilan berpikir, pemecahan masalah dan keterampilan intelektual, menumbuhkan kemampuan kerja sama, dan mengembangkan sikap sosial. Model pembelajaran PBL dirancang masalah-masalah yang menuntut siswa mendapatkan pengetahuan yang penting, membuat mereka mahir dalam memecahkan masalah, dan memiliki strategi belajar sendiri serta memiliki kecakapan berpartisipasi dalam tim. Pembelajaran dengan model PBL diharapkan memberikan kesempatan pada siswa untuk dapat meningkatkan keterampilan kerja ilmiahnya.

Nurhadi (2004) menyatakan bahwa PBL adalah suatu model pembelajaran yang menggunakan masalah dunia nyata sebagai suatu konteks bagi siswa untuk belajar tentang cara berpikir kritis dan keterampilan pemecahan masalah serta untuk memperoleh pengetahuan dan konsep yang esensial dari materi pelajaran. Hal ini sesuai dengan pendapat Sholihah (2010) yang menyatakan bahwa dalam pembelajaran PBL guru memberikan permasalahan dari dunia nyata kepada siswa untuk dipecahkan bersama. Saat membahas dan menjawab masalah, siswa harus terlibat dalam kegiatan nyata misalnya mengobservasi, mengumpulkan data dan menganalisa bersama siswa lain dalam kelompok atau di dalam kelas. Selama siswa belajar di sekolah, siswa akan dihadapkan pada soal-soal untuk dipecahkan dan diatasi. Tugas siswa adalah untuk mencari penyelesaian masalah tersebut dengan pengalamanpengalaman di sekolah yang dirancang oleh guru. Setelah tamat pendidikan sekolah, siswa masih akan dihadapkan pada macam-macam persoalan yang harus diatasi, diharapkan bahwa pengalaman di sekolah akan membantu dalam mencari suatu penyelesaian.

PBL merupakan simulasi masalah yang dapat digunakan untuk mengaktifkan keingintahuan siswa sebelum mulai mempelajari suatu objek, sehingga siswa mampu berpikir secara kritis serta mampu untuk mendapatkan dan menggunakan sumber-sumber pembelajaran dengan tepat.Secara garis besar, PBL merupakan pembelajaran yang menuntut siswa untuk belajar mandiri secara individu maupun kelompok dalam memecahkan masalah yang disajikan oleh guru. Guru berperan menyajikan masalah dan mengajukan pertanyaan yang mengarahkan siswa untuk memecahkan suatu masalah dalam kegiatan pembelajaran (Mokhtar, 2013).

Sardiman (2009) menyatakan hasil belajar merupakan hasil pencapaian dari tujuan belajar. Sardiman juga mengemukakan tentang hasil belajar yang meliputi bidang keilmuan dan pengetahuan (kognitif), bidang personal (afektif) serta bidang kelakuan (psikomotorik).Hasil belajar dipengaruhi oleh pengalaman subjek belajar dengan dunia fisik dan lingkungannya.

Hasil belajar seseorang tergantung pada apa yang telah diketahui siswanya, tujuan, motivasi yang mempengaruhi proses interaksi dengan bahan yang sedang dipelajari (Suparno, 2011).

Tulisan ini dimaksudkan untuk mendeskripsikan penerapan model pembelajaran problem based learning (PBL) terhadap hasil belajar siswa SMAN 7 Palu pada materi larutan penyangga.

\section{Metode}

Tempat penelitian yaitu dilaksanakan di SMAN 7 Palu.Populasi dalam penelitian ini adalah semua siswa kelas XI di SMAN 7 Palu yang terdaftar pada tahun ajaran 2014-2015 sebanyak 2 kelas. Sampel dari penelitian ini berjumlah 23 orang siswa dalam kelas XI IPA 3 dan 23 orang siswa dalam kelas XI IPA 4 dimana, dipilih dua kelas secara purposive sampling (pemilihan sampel berdasarkan pertimbangan) yaitu kelas yang mempunyai hasil belajar siswa relatif sama dalam proses belajar kimia sehingga dapat dianggap kedua kelas ini mempunyai kemampuan awal yang sama. Teknik pengambilan sampel yang dilakukan yaitu pengambilan sampel dengan cara purposive sampling dengan melihat hasil ujian semester sebelumnya (mid semester).

Instrumen yang digunakan pada penelitian ini adalah tes hasil belajar kimia sebanyak 40 soal berbentuk pilihan ganda (multiple choice) yang variable dan reliable dengan pilihan jawaban sebanyak 5 (lima) pada masing-masing soal. Tes hasil belajar siswa disusun dengan maksud untuk memperoleh data hasil belajar siswa kelas XI IPA pada materi larutan penyangga di SMAN 7 Palu.

Penelitian ini dilaksanakan dalam tiga tahap yaitu tahap persiapan, tahap pelaksanaan, dan tahap akhir. Adapun tahap-tahap tersebut adalah sebagai berikut:

\section{Tahap persiapan}

Observasi lokasi penelitian; menentukan populasi dan sampel penelitian; menyusun instrumen tes, skenario pembelajaran, multimedia dan LKS yang akan digunakan dalam penelitian untuk kelas eksperimen dan kelas kontrol. 


\section{Tahap pelaksanaan}

Pemberian tugas awal sebelum melakukan perlakuan atau proses belajar (pretest); Pemberian perlakuan (penyajian materi); Kelas XI IPA 3 yang dijadikan kelas eksperimen diberikan perlakuan dengan menggunakan model pembelajaran PBL dan kelas XI IPA 4 sebagai kelas kontrol menggunakan konvensional; pemberian tes evaluasi pada kelas eksperimen dan kelas kontrol untuk memperoleh data hasil belajar siswa(posttest).

\section{Tahap akbir}

Kegiatan yang dilakukan pada tahap ini adalah pengumpulan, pengolahan, dan analisis data serta pelaporan hasil penelitian.

\section{Hasil dan Pembahasan}

Hasil perhitungan data penelitian yang didapat dari posttest kelas eksperimen (model pembelajaran PBL), diperoleh nilai tertinggi sebesar 97 dan nilai terendah 67 , nilai rata-rata $(M)$ 82,61; standar deviasi $(S D)$ sebesar 6,83 dan varians $\left(s^{2}\right)$ sebesar 46,70. Sedangkan hasil perhitungan data penelitian yang didapat dari posttest kelas kontrol (model pembelajaran konvensional), diperoleh nilai tertinggi sebesar 90 dan nilai terendah 63, nilai rata-rata $(M) 78,65$; standar deviasi $(S D)$ sebesar 7,47 dan varians $\left(\mathrm{s}^{2}\right)$ sebesar 55,87 .

\section{Uji normalitas}

Uji normalitas dua sampel menggunakan uji Kolmogorov-Smirnov diperoleh nilai untuk kelas eksperimen Sig 0,20 > 0,05 dan untuk kelas kontrol $0,20>0,05$ yang berarti kedua data terdistribusi normal.

\section{Uji homogenitas}

Uji homogenitas diperoleh nilai $\mathrm{F}_{\text {hitung }}$ $0,376>0,543 \quad F_{\text {tabel }}$ untuk kelas eksperimen Sig $0,200>0,05$ dan untuk kelas kontrol 0,200>0,05 yang berarti kedua data terdistribusi normal. Tabel diatas menunjukan hasil uji homogenitas dengan metode Lavene's test.yang berarti terdapat kesamaan varians antar kelompok atau yang berarti homogen.

\section{Uji hipotesis}

Pengujian dilakukan untuk mengetahui apakah skor tes akhir (post test) kelas eksperimen yang diberikan pembelajaran dengan menggunakan model pembelajaran PBL lebih besar dibandingkan dengan skor tes akhir kelas kontrol yang diajarkan menggunakan model pembelajaran konvensional. Untuk pengujian tersebut diajukan hipotesis sebagai berikut:

Ho: Tidak ada perbedaan hasil belajar siswa yang menggunakan model pembelajaran PBL dengan pembelajaran konvensional;

Ha: Ada perbedaan hasil belajar siswa dengan menggunakan model pembelajaran $\mathrm{PBL}$ dengan model konvensional. Jika harga Sig melebihi 0,05 maka
Tabel 1. Data deskripsi kelas eksperimen dan kelas kontrol

\begin{tabular}{|c|c|c|}
\hline \multicolumn{3}{|l|}{ KELAS KONTROL } \\
\hline Mean & 78,65 & 1,55 \\
\hline $\begin{array}{l}\text { 95\% Confidence Interval for Mean } \\
\text { (Lower Bound) }\end{array}$ & 75,42 & 9 \\
\hline $\begin{array}{l}95 \% \text { Confidence Interval for } \\
\text { Mean(Upper Bound) }\end{array}$ & 81,88 & \\
\hline 5\% Trimmed Mean & 78,86 & \\
\hline Median & 80,00 & \\
\hline Variance & 55,874 & \\
\hline Std. Deviation & 7,475 & \\
\hline Minimum & 63 & \\
\hline Maximum & 90 & \\
\hline Range & 27 & \\
\hline Interquartile Range & 10 & \\
\hline -Skewness &,- 253 & 481 \\
\hline -Kurtosis &,- 403 & ,935 \\
\hline \multicolumn{3}{|l|}{ KELAS EKSPERIMEN } \\
\hline Mean & 82,61 & 1,42 \\
\hline $\begin{array}{l}\text { 95\% Confidence Interval for Mean } \\
\text { (Lower Bound) }\end{array}$ & 79,65 & 5 \\
\hline $\begin{array}{l}95 \% \text { Confidence Interval for Mean } \\
\text { (Upper Bound) }\end{array}$ & 85,56 & \\
\hline 5\% Trimmed Mean & 82,66 & \\
\hline Median & 83,00 & \\
\hline Variance & 46,704 & \\
\hline Std. Deviation & 6,834 & \\
\hline Minimum & 67 & \\
\hline Maximum & 97 & \\
\hline Range & 30 & \\
\hline Interquartile Range & 7 & \\
\hline Skewness &,- 120 & 481 \\
\hline Kurtosis & ,394 & ,935 \\
\hline
\end{tabular}

$\mathrm{H}_{0}$ ditolak, begitupun sebaliknya. Data yang dihasilkan nilai signifikan menurut uji statistik menggunakan uji-t dua pihak didapatkan nilai signifikansinya sebesar 0,068 yang berarti nilai Sig $>0,05$ sehingga dengan demikian $\mathrm{H}_{0}$ ditolak dan $\mathrm{H}_{\mathrm{a}}$ diterima dan dapat disimpulkan bahwa terdapat perbedaan antara hasil belajar siswa dengan menggunakan model pembelajaran PBL dengan model konvensional.

Penelitian dilaksanakan pada kelas eksperimen (XI IPA 3), dengan menerapkan model pembelajaran PBL, dan kelas kontrol (XI IPA 4) dengan menerapkan model pembelajaran konvensional. Sebelum pembelajaran dilaksanakan, terlebih dahulu dilaksanakan pretest pada kedua kelas untuk mengetahui kemampuan awal siswa kedua kelas sampel mengenai materi larutan penyangga. Kemampuan awal siswa yang dinilai melalui pretest meliputi hasil belajar (aspek kognitif) siswa. Kemampuan awal siswa aspek kognitif dinilai dari jawaban soal pilihan ganda sebanyak 30 butir soal.

Hasil analisis data pretest hasil belajar siswa kelas eksperimen dengan menerapkan model pembelajaran PBL dan kelas kontrol yang diajar dengan menerapkan model pembelajaran konvensional, diperoleh rata-rata nilai kelas 
eksperimen adalah 28,40 dan kelas kontrol adalah 28,55 . Berdasarkan hasil tersebut, bahwa rata-rata nilai pretest hasil belajar kelas eksperimen lebih rendah dari pada rata-rata nilai pretest hasil belajar kelas kontrol namun tidak terdapat perbedaan yang signifikan, sehingga dapat disimpulkan bahwa kemampuan awal siswa kelas eksperimen dan kelas kontrol relatif sama. Dari hasil analisis nilai posttest siswa diketahui bahwa rata-rata nilai hasil belajar kelas eksperimen sebesar 82,60 dan kelas kontrol sebesar 78,69.

Setelah dilakukan uji-t sampel dapat dilihat ratarata pretestsiswa pada kelas PBL hampir samadengan kelas konvensional. Rata-rata posttest siswa pada kelas PBL lebih tinggi dibandingkan dengan kelas konvensional ini berarti kedua kelas berbeda. Perbedaan dari penggunaan kedua model pembelajaran tersebut membuat hasil posttest yang diperoleh siswa menjadi berbeda. Kenyataan ini menunjukkan bahwa hasil belajar aspek kognitif antara siswa yang menggunakan model pembelajaran PBL lebih tinggi dari pada kelas yang menggunakan model pembelajaran konvensional. Model pembelajaran PBL siswa diarahkan untuk memiliki keinginan untuk memahami, mempelajari kebutuhan pembelajaran yang baik sehingga mau menggunakan dan mencari sumbersumber pembelajaran yang terbaik dalam rangka pemecahan masalah yang dihadapi, sehingga siswa mampu berpikir secara kritis serta mampu untuk mendapatkan dan menggunakan sumber-sumber pembelajaran dengan tepat.

Berdasarkan hasil analisis uji-t sample. Diketahui bahwa hasil belajar awal oleh siswa pada materi pokok larutan penyangga pada kelas eksperimen (model pembelajaran PBL) dan kelas kontrol (model pembelajaran konvensional) tidak berbeda signifikan karena setelah dilakukan postest pada kedua kelas didapatkan hasil sebagai berikut, pada kelas PBL ketuntasan klasikal adalah 83\% dan pada kelas konvensional ketuntasan klasikal adalah $79 \%$. Hasil belajar yang lebih tinggi pada kelas eksperimen yang menggunakan model pembelajaran PBL dikarenakan model pembelajaran ini memiliki kelebihan dibandingkan dengan model konvensional. Hal ini sesuai dengan hasil penelitian oleh Sholihah (2010) menyatakan bahwa peran guru dalam pengajaran berbasis masalah adalah menyajikan masalah, mengajukan pertanyaan, memfasilitasi penyelidikan dan dialog. Pengajaran berbasis masalah tidak dapat dilaksanakan jika guru tidak mengembangkan lingkungan kelas yang memungkinkan terjadinya pertukaran ide secara terbuka. Intinya, siswa dihadapkan pada situasi masalah yang otentik dan bermakna yang dapat menantang siswa untuk memecahkannya.

PBL mengarahkan siswa untuk memiliki keinginan untuk memahami, mempelajari kebutuhan pembelajaran yang baik sehingga mau menggunakan dan mencari sumber-sumber pembelajaran yang terbaik dalam rangka pemecahan masalah yang dihadapi. Model pembelajaran berbasis masalah (PBL) merupakan suatu cara penyajian bahan pelajaran dengan menghadapkan siswa pada persoalan yang harus dipecahkan atau diselesaikan dalam rangka mencapai tujuan pendidikan (Trianto, 2007).

Oleh karena itu, penggunaan model pembelajaran PBL diharapkan dapat melatih siswa disiplin dan meningkatkan pemahaman dalam pelajaran kimia, serta mampu membangun kreativitas siswa dalam memunculkan ide-ide untuk membuat soal atau menemukan jawaban dari situasi yang ada. Melalui model pembelajaran ini, siswa juga diharapkan dapat mengembangkan pemahaman yang telah didapat sehingga siswa mampu membangun pengetahuannya sendiri dan mengembangkan pengetahuannya yang sederhana hingga pengetahuan yang kompleks.

Penggunaan model pembelajaran PBL mengharuskan siswa mengidentifikasi permasalahan, mengumpulkan informasi dan menggunakan informasi tersebut untuk memecahkan masalah. Pembelajaran ini siswa diharapkan dapat mengembangkan keterampilan berfikir dalam memecahkan masalah dan menjadi pelajar yang mandiri sehingga prestasi belajar meningkat. Agar pelaksanaan model pembelajaran ini lebih afektif, maka dapat dilaksanakan model pembelajaran basis masalah melalui metode eksperimen dan inkuiri terbimbing. Melalui model berbasis masalah, siswa akan mampu memecahkan masalah. Sedangkan dengan metode eksperimen dan inkuiri terbimbing, siswa dapat mengamati, menganalisis dan menyimpulkan hasil pengamatan secara mandiri (Cheong, 2008).

Disamping ketepatan penggunaan model dan metode pembelajaran, kreativitas juga merupakan salah satu faktor pendukung keberhasilan belajar siswa dan salah satu karakteristik yang dimiliki oleh individu. Kreativitas adalah hasil dari interaksi antara individu dan lingkungannya. Kemampuan kreatif dapat ditingkatkan melalui pendidikan. Kreativitas sangat diperlukan untuk meningkatkan kualitas hidupnya, karena untuk menghadapi masa globalisasi, maka siswa harus mempunyai daya saing yang tinggi. Siswa yang kreatif mampu melakukan inovasi yang baru dalam memecahkan masalah yang mereka hadapi dalam kegiatan belajar mengajar maupun dalam kehidupan seharihari (Munandar, 2004).

\section{Kesimpulan}

Hasil belajar siswa untuk nilai rata-rata kelas eksperimen lebih besar dari kelas kontrol yaitu untuk kelas eksperimen adalah 82,61 dan untuk kelas kontrol yaitu 78,65. Uji normalitas menggunakan uji Kolmogorov-Smirnov dimana diperoleh nilai untuk kelas eksperimen Sig 0,20 > 0,05 dan untuk kelas kontrol 0,20>0,05 yang berarti kedua data terdistribusi normal. Uji homogenitas menggunakan uji Lavene Statistics dimana diperoleh nilai $\mathrm{F}_{\text {hitung }} 0,37>0,54 \mathrm{~F}_{\text {tabel }}$ untuk kelas eksperimen Sig 0,20>0,05 dan untuk kelas kontrol 0,20>0,05 yang berarti kedua data 
terdistribusi normal yang berarti terdapat kesamaan varian antar kelompok atau yang berarti homogen. Hasil uji hipotesis menggunakan uji-t dua pihak didapatkan nilai signifikansinya sebesar 0,06 yang berarti nilai Sig $>0,05$, sehingga Ho ditolak dan $\mathrm{Ha}$ diterima, yang artinya model pembelajaran $\mathrm{PBL}$ pada materi larutan penyangga berpengaruh positif terhadap hasil belajar siswa di SMAN 7 Palu.

\section{Ucapan Terima Kasih}

Penulis mengucapkan terimakasih kepada Salim selaku Kepala sekolah SMAN 7 Palu, Siti Hajar selaku Guru Kimia di SMAN 7 Palu dan siswa kelas XI IPA 3 dan XI IPA 4 SMAN 7 Palu.

\section{Referensi}

Cheong, F. (2008). Using a problem based learning approach to teach an intelligent systems course. Journal of Information Technology Education, 7, 47-59.

Mokhtar. (2013). Motivation and performance in learning calculus through problem based learning. International Journal of Asian Social Science, 3(9), 50-60.

Munandar, U. (2004). Pengembangan kreativitas anak berbakat. Jakarta: PT Rineka Cipta.

Nurhadi. (2004). Kurikulum 2004 pertanyaan dan jawaban. Malang: Grasindo.

Rahayu. (2012). Pengembangan pembelajaran IPA terpadu dengan menggunakan model pembelajaran problem base melalui lesson Study.http://journal.unnes.ac.id/nju/index.php /jpii/article/download/2014/02:25.[23 November 2014].

Rubi, A, P. (2012). Penerapan model pembelajaran berbasis masalah (problem based learning) untuk meningkatkan prestasi belajar siswa pada mata diklat praktik dasar instalasi listrik (PDIL) di SMK Muhammadiyah 3 Yogyakatra. Skripsi. Yogyakarta: Universitas Negeri Yogyakarta.

Sardiman, A, M. (2009). Interaksi dan motivasi belajar mengajar. Jakarta: Radjagrafindo Persada.

Sholihah, I. (2010). Penerapan model pembelajaran problem based learning (PBL) untuk meningkatkan partisipasi dan keaktifan berdiskusi siswa dalam pembelajaran biologi kelas VII SMP Negeri 2 Surakarta. Skripsi Sarjana. Surakarta: Program Studi Pendidikan Biologi FKIP Universitas Sebelas Maret. Tidak Diterbitkan.

Sudjana, N. (2010). Dasar-dasar proses belajar mengajar. Bandung: Sinar Baru Algesindo.

Suparno. (2011). Pengembangan bahan ajar mata diklat adaftif berbasis web based learning pada sekolah menengah kejuruan jurusan teknik bangunan. Jurnal Teknologi dan Kejuruan, 34(1), 65-70.

Tosun, C. (2011). The effect of problem based learning on student motivation towards chemistry classes and on learning strategies. Journal of Turkish Science Education, 9(1), 4555.

Trianto. (2007). Model-model pembelajaran inovatif berorientasi konstruktivistik. Jakarta: Prestasi Pustaka.

Wahyudi, S, B., Hariyadi, S., \& Hariyani, S. A. (2014). Pengembangan bahan ajar berbasis model problem based learning (PBL) pada pokok bahasan pencemaran lingkungan untuk meningkatkan hasil belajar siswa kelas X SMA Negeri Grujugan Bondowoso. Pancaran, 3(3), 83-92. 